\title{
MARKETING AND BRANDING IN ISLAMIC COUNTRIES, CHALLENGES AND CAPACITIES
}

\author{
M. Tabatabai Nasab ${ }^{*}$ and B. Banejad \\ Department of Business Administration, Faculty of Economics, Management and Accounting, \\ University of Yazd, Iran
}

Published online: 15 May 2016

\begin{abstract}
In this paper, after presenting the basic concepts, capabilities and challenges of branding and marketing in Muslim countries are examined. The main objective of this paper is to describe and explain the challenges of branding and marketing potential in Islamic countries and expressing its potential capacities. Method of study is library and studying is primarily descriptive and analytical. This paper shows that there are a lot of areas and opportunities for branding and marketing in Islamic countries. On the other hand, many factors can create barriers to the growth of the brands coming from the Muslim world. However, if the right strategies are used, these challenges are not insurmountable. Creating products with a unique identity, based on basic goals and values of Islam and a reviving culture of innovation and development of innovative and competitive marketing strategies are of proposed methods to eliminate obstacles in the Islamic branding and marketing.
\end{abstract}

Keywords: Islamic branding; islamic marketing; islamic branding challenges; islamic branding capabilities.

Author Correspondence, e-mail: smtnasab@yahoo.com

doi: http://dx.doi.org/10.4314/jfas.v8i3s.257 


\section{INTRODUCTION}

When we use the words "Islamic branding and marketing," we do not mean just the brands available in Islamic countries, although these brands are known as the Islamic branding, but also any brand that seeks to meet the needs of Islamic markets. Our definition of Islamic branding and marketing refers to any activity related to branding and marketing of countries, products and services to an Islamic audience, regardless of whether they are in the countries with Muslims as majority or minorities of Muslims or have Muslim ruler or not. Therefore, our definition is not limited to branding and marketing related to companies whose ownership is by Muslims, but also includes companies not owned by Muslims but provide Muslims' needs. Therefore, non-Muslim brands are under this title if they are looking to build brands to gain market share in countries with majority or minority of Muslims. In fact, many brands that now provide Muslim audience's needs are mostly related to non-Muslims companies and often the West. It is expected that the population of the Muslim world with a growth rate of 35 percent reach 2.2 billion by 2030, and this figure is expected as equivalent to 26.4 percent of total projected population in the world with a population of over 8.3 billion (Temporal, 2011).

\section{Concepts related to Islamic branding and marketing}

\section{Do branding and religion have the ability to combine?}

Some experts do not see the combination of religion with branding and marketing as satisfactory but others do not think so. From the perspective of the market, meeting the real needs of customers is desirable and if we think that Islam as a religion has no impact on needs and markets related to supplying these needs, it is not true. However, the Muslims markets in countries with a Muslim majority or Muslim minority have never been properly investigated. Opening of Muslims markets and increase in immigration of Muslims to the West as a significant and growing minority means that we can no longer ignore their needs (Temporal, 2011). The market segmentation based on religion has always been bothersome and many executives and business leaders insist that they do not sell religion, but they are looking for supplying desirable goods and services needed and requested in a crowded market. With such a broad definition, Islamic branding is not only an issue relating to a religion, but it is building the brands that compared to ordinary brands have been revised for large religious populations. In fact, considering such an issue is not simply because of attention to a group of consumers who have a particular religion. On the contrary, it is to focus on the needs of a large and growing population defined by common values and practices (Temporal, 2011). 


\section{MUSLIMS MARKET, A GROWING BUT NEGLECTED MARKET}

While many countries and companies are involved in a fast competition to get the market in populous countries such as China and India to expand their business and develop their brands, the largest market in the world has largely been ignored. Today, Muslims constitute nearly 1.6 billion of the world population. This market is a potential source for Western and Muslim countries brands and can put them on a new growth path. By 2030, it is expected that the Islamic world's population with a grow rate of 35 percent reach 2.2 billion, an make up 26.4 percent of the world's total projected population that is over 8.3 billion.

Moreover, by 2030, it is expected that 79 countries have one million or more Muslim inhabitants, while the number of these countries is now 72. The majority of Muslims in the world (over 60\%) will continue to live in the Asia-Pacific region, and it is despite the fact that $20 \%$ of them live in the Middle East and North Africa. Moreover, Muslims will remain in Europe and America as a relatively small minority, but will form a growing proportion of the total population of these areas.

Across the Middle East, Asia, Africa, and Europe, even in countries with a Muslim majority and the Muslim minority, business activities are increasing and the worth of Islamic business is estimated as thousands of billions of dollars.

Many Western multinational companies consider this large market. For example, Nestlé is now producing many of its brands using Halal processes, and through collaboration with Halal accreditation agencies is on the fast-track growth in Islamic markets. Only in 2008, American Nestlé earned \$ 5.2 billion income through producing halal products. Several Western fast food chains such as McDonald's, KFC, and Metro are setting up more branches that offer halal products and services. Muslim consumers as a group of world citizens demand the newest, most beautiful, and best products to ask from the West. They adore Western brands - such as Manchester City, Aston Martin, and Harrod - and want to use their products more. However, for various reasons, Muslims in the West wholeheartedly tend to develop their own brands.

First, Western brands do not often match with Islamic Sharia law and so are not in the circle of Halal products from the Muslims perspective. Although this will not affect in cases such as luxury cars or common components, in products such as food and beverage, pharmaceutical, cosmetic, and medical products, and some services, it is quite influential.

In such cases, brand managers will have to make integrated marketing strategies to create international brands in countries with Muslim population. 
Secondly, the growing educated middle class in Islamic societies and Muslim countries has created an incentive to develop the business, products, and customized services that can compete with well-established and popular brands.

Thirdly, from a national perspective, Muslim governments tend to become global brands rather than local brands because they know how brand strength can cause economic cooperation and formation of the national picture. In particular, they have realized that, it seems that to promote intangible assets, such as strong business brands as a mature, stable, and growing fundamental economic characteristic.

The fourth and most important reason is that many Muslim countries are looking to diversify their business interests and less reliance on resource-based industries and limited supply.

Thus, in the current period, there is a significant increase in the demand of Islamic countries and companies to develop global and original brands, which shows the necessity of application of techniques and skills of branding and marketing in the West.

However, any company, whether Islamic or non-Islamic, wanting to capitalize on the brand and business opportunities must understand that Muslims market as a whole is not homogeneous, and like similarities in consumer behavior across Muslim countries, there are many differences.

\section{Islamic countries' trade}

Islamic countries' trade occurs in two forms: Islamic countries' trade with Islamic countries and Islamic countries' trade with the outside world. Studies have shown that Islamic countries' trade with each other constitutes about 10 percent of total trade and 90 percent is the Islamic countries' trade with other countries taking place mainly in the West (Naderan, 2003, 31) that is the Islamic countries market is under the control of West multinational markets. Thus, despite the efforts of organizations, unions and trade agreements show very low economic cooperation. The main factor in the lack of political tension occurs between economic interactions and lack of fundamental studies in the fields of economic cooperation. If the context of economic interactions exists with decent adaptations in the Islamic countries, Islamic countries will reach the unity and cultural political cooperation.

Although in recent centuries, Islamic countries have tried hard to promote cooperation in cultural, political, economic fields and achieving Islamic unity, and every year by holding meetings and discussions have tried to reach an agreement and submit plans to achieve contribution to the unity, Organization of Islamic Cooperation (OIC) is an outcome of such efforts and some other Islamic institutions can be the result of such an attempt, these meeting 
and further discussion have mostly been on political and military issues and resolving political tensions and problems. Although Islamic countries have reached several agreements on economic cooperation as well, like economic unity council including Arabs and Arab Common Market, Persian Gulf Cooperation Council, ECO and Maghreb Union, these agreements have still not been successful and the level of economic interactions among Islamic countries has actually been low. However, it can be said that the existence of these agreements paves the ground for practical cooperation among Islamic countries and further study of these agreements and movements, and better and more efficient and effective practical strategies and mechanisms will arise to build a real consensus among Islamic countries in the region as the result of these studies.

Now, the process of globalization has created hopes that the process of regional economic interactions among Islamic countries may reach high levels.

\section{Islamic countries, areas of convergence and obstacles}

Islamic countries due to ideological confrontation with the West have appropriate grounds of potential interactions convergence in the political, economic, and social areas. Lasting and permanent presence of the West in order to suck the economic arteries in the Muslim world, colonial history of Muslim countries, and crisis creating of the West in Islamic communities at the present juncture are all raised as a major and inclusive threat for the Muslim world. This can urge Muslim countries to have a joint defense strategy and act as the main factor of integration.

\section{AREAS OF CONVERGENCE}

\section{Areas of integration include}

1. Consistency of values and overlapping of public values such as: moral issues, ideological worldview, and attitude

2. Consistency of lifestyle and patterns of social relations, such as traditions, practices, and norms

3. Administrative capacity, political abilities, and the quality of political behavior and interactions related to this field

4. Economic growth (balanced economic level), for example, in the West has created broad and deep economic growth, balanced economic level, and increasing economic interactions and convergence. In addition, the interconnected social communication has created the 
plurality of social mobility remiss in the context of economic, cultural, and political interactions.

5. Balanced level of human and technological capital: this issue very clearly shows the multiplicity of technical, cultural, and informational interactions.

Sometimes the convergence is created because of a common feeling of a threat and interest. A large number of treaties, covenants, and conventions that took place in the contemporary era are indicative of this issue.

Whenever the West has felt danger has given common response and to maintain political, economic, social resources has searched strategies and a shared determination.

Convergence in the form of regional, continental, and world unity today shows a common look to the global developments. Today, in fact, convergence is telling of the common destiny.

For example, European Union is a symbol of a very large continental convergence. The West suggests a transnational ideological convergence that connects correlation at micro and macro-level social levels at national and international levels. Common geopolitical space today is considered as the origin of convergence.

Thus, the convergence of Islamic countries is well formed through geopolitical space, shared fundamental ideological beliefs, consistency of values, similar cultural, political, and social structure.

In addition, lack of social development in cultural, political, and economic aspects in all Muslim countries reminds the need to achieve a high level of development as a common desire and goal. This case and coping with threats from the West are of the factors of convergence of the Muslim world.

\section{Barriers to convergence}

1. Lack of social forms and lack of institutionalizing infrastructure, Islamic countries, and societies within it do not have a functional and content social order. In other words, civil societies and cultural forms existing in Islamic countries are not formed of civil cultural and historical experience, but based on cultural and social policymaking, the government has emerged. As a result, such institutions do not have independent functioning.

2. Non-democratization of the government: most governments in Muslim countries act against the people and social institutions in a non-democratic way and monitor internal and external relations of individuals and social institutions, and make them act in line with the political goals of the government. 
3. Unknown vital macro goals and drawing them and a lack of common understanding of the benefits

4. Lack of transnational institutions in the form of religious and Islamic identity that can have free practice in order to strengthen Islamic identity

5. Dependence on big powers that has deeply influenced the behavior of nation-state in the Islamic countries that is imposed with the pretext of security, and promoting social development, but they interfere in the internal affairs and create tension and hostility among Muslim communities (Nozari, 2004, 111).

Now that processes of globalization show different convergences dominant at national, regional, geographic, and continental levels, Muslim world with the use of IT can achieve high levels of integration.

\section{The number of markets; similarities and differences}

Here some of the examples of the similarities and differences in global markets of Muslims that affect the brand and marketing strategies will be discussed.

Similarities

- Common faith, values, and Muslim identity

- Similar dietary requirements (halal)

- Lifestyles similar requirements (economy, education, entertainment, and so on)

- The existence of a deep sense of community and well-being

Difference

- Different Places

- Various languages and numerous dialects

- Cultural differences and different ways of life

- Varying degrees of Islamic piety

- Varying degrees of education, welfare and complexity of marketing

The meaning of this lack of uniformity is that, although a global brand strategy may be caused by a global value proposition, brand managers and marketers have to make integrated marketing strategies to create international brands in countries with population of Muslims.

The annual value of the global market for halal food is estimated to be about 650 billion dollars and this represents a great opportunity for international companies for globalization. In addition to the complexity of the market situation, the reality is that many of the world's Muslim population is relatively economically weak and are living in countries with developing economies. Marketers should consider this issue, but they also have to consider 
that as the economy develops and people gain spending power, then branding and marketing opportunities will be created.

For example, the largest Muslim minority is in India with 161 million and most of them are in the middle class who want to buy their brands in case of increase in their purchasing power. Other countries such as Bangladesh, a large country with a Muslim majority, are yet not at this stage of development.

The opportunity to buy luxury goods in countries with Muslim-majority is mostly related to elite class, especially in the Persian Gulf. Thus, marketers to search for product market should pay attention to the degree of development of society goal to find out which products are suitable for those markets and understand the consumer behavior in each section. Governments also need to understand the different markets, so that they can encourage and assist appropriate industries for the future.

It is clear that careful research to understand the markets Muslims correctly, especially in the field of consumer behavior is required. However, many opportunities exist for marketers in all categories, which can be followed. In addition, from the perspective of brand management, global Muslim market can be seen as a market of lifestyle associated with Islamic values and principles, the values and principles that seriously affects the daily lives of all Muslims.

\section{ISLAMIC BRANDING AND MARKETING OPPORTUNITIES}

Despite the differences in markets regarding size and behavior of the consumer markets around the world, Muslims market creates many capacities for producer to produce goods and services, some of which are mentioned below:

\section{Food \& Beverage}

As mentioned earlier, the annual value of the global market for halal food is estimated to be about 650 billion dollars and this represents a great opportunity for international companies for globalization. Some Muslim countries companies are trying to develop their own brands and some Islamic governments help them by creating time and place facilities and guiding them to find markets for their products. However, now many branding opportunities are taken by Western global brands such as Nestle. (Rusta and Salehi, 2012)

\section{Education}

There are a large number of Islamic educational institutions at the primary, middle and high schools, which according to statistics is also on the rise. It is estimated that by 2050, Muslims form 60 percent of the population under 18 years of world. Youth market represents a broad 
perspective in the future, and despite the increase in worldwide access to the Internet and information across the world, research shows that they still have a tendency to preserve Islamic values.

\section{Tourism and Hospitality}

Travel, tourism, and Islamic leisure are other parts of the Islamic market that offers especial products and services for Muslims and non-Muslims. From tourist destinations in the Middle East to halal airlines, hotels, and resorts with full halal services are things existing for everyone, and many Muslim-majority countries are trying to invest in the growth of tourism and tourism-related travel.

Fully Islamic Tourism and Hospitality are slowly but surely growing like companies such as hotels and apartments of Johareh, in which the sharia laws are observed.

\section{Medical, pharmaceutical, cosmetics, and personal care}

This section is another part of the Islamic world market that promises great gains. For many Muslims who want to act in accordance with Sharia law and consume only what is halal, there is a growing industry in the areas of general medicine, medicine, health, and medical products that do not contain ingredients non-compliant with sharia such as gelatin derived from the meat of animals prohibited. The growth of these industries,...

\subsection{Entertainment}

Art, sports, and entertainment can be fun for everyone and thousands of television channels around the world are dedicated for Muslim consumer that are usually different in terms of content in different countries. Even in Muslim-minority countries, brands related to entertainment are emerging; an example of this is Islam Channel in the UK.

\section{Digital and Internet products and services}

Internet, Media, and digital products of the region perhaps provide the most exciting opportunities to those who are willing to serve the Islamic markets. Muslims can now have access to digital libraries, digital art, photography, and other products. Global brands also see market potential in the digital space.

For example, in August 2009, LG mobile phone manufacturer offered a new phone to market with some special features including a Qiblah indicator, prayer time alarm as well as Quran software, Hijri calendar and a Zakat calculator. Moreover, the growth of networked societies provides many opportunities in the media area, where brands such as maxim.com, the world's largest Muslim lifestyle media company, help individuals and business activities to link to each other in the Muslim market. 


\section{Financial products and services}

Over the past twenty years, there have been a number of banks offering Islamic financial services and countries and cities such as Malaysia, Singapore, Hong Kong, and London competing to invest in this process and become a regional Islamic financial hub. After the recent global economic downturn, issues of distrust in conventional banking system created an added incentive for the growth of Islamic finance. This is while in the conventional banking system crisis between 2007 and 2009, it caused chaos in many countries.

The resilience of the Islamic financial system has led some actors and observers in the financial industry call it "ethical finance issues." Another part of the rapid growth of Islamic economics is partly because the Islamic financial system is based on principles that Muslims and non-Muslims customers have accepted.

The following are some of the causes of the stability of the Islamic banking system.

- Money creation in Islamic banking system is mostly based on the creation of share and less based on creating debt. For this reason, Islamic banking is more stable and less risky compared to capitalism banking.

- Islamic banking has no risk of interest rates. The lack of risk leads to lower economic volatility and greater economic stability. Using Islamic contracts (participation and exchange) instead of interest has more efficiency, because in Islamic banking, "rate profitability" rather than "credit rating" is used. This ranking leads to optimal allocation of resources and has more efficiency than the credit rating system.

- In the capitalist banking system features such as speculation, the lack of synchronization of bank commitments with receipts, and the emergence of financial instability are created by debt markets. This is while Islamic banking system does not have these economydestabilizing features. Equity of commitments with received payments is one of the reasons for stability of Islamic banking.

- Islamic banking system has the ability to absorb the real shocks to the real economy through creating the appropriate changes in the cost of capital. With the change of profitability in the Islamic banking system, the cost of capital changes in accordance with the profit, but in capitalism banking system, the interest rate does not change according to the change in profitability. This may lead to severe reactions in demand for finance and thus lead to the financial crisis.

- In the Islamic banking system, risk is distributed between the capital provider and the applicant for capital, but this risk in the banking system of capitalism is only for the applicant 
of the capital. Thus, Islamic banking has a lower risk in comparison with the capitalist banking.

- Financing through borrowing creates a wide debt market. Frequent buying and selling of loans with interest rates leads to the development of the debt market and increased default risk (non-repayment of loans) leading to a financial crisis. The recent financial crises in the US and Europe are typical examples of this fact. However, due to the principle of participation in profit and loss, Islamic banking system does not lead to extend of debt market.

- Transaction cost in Islamic financing system is less than this cost in conventional systems that is due to the higher correlation between the financial sector and the real sector in the Islamic banking system.

- In the capitalist banking system, credit sector is formed independent of the real sector in such a way that each section follows his own specific goals. As a result, the growth of the two markets may not have the necessary coordination and one market has more growth than the other does. However, in the Islamic banking system, coordination between credit and real sector takes shape, so that financial market growth depends on the growth of the real sector.

- In the discussion of Islamic banking profit issue arises that is different from usury (interest), meaning receiving any surplus amount on debt, if the condition is already set. The interest ratio is determined by mutual consent and paid so, but in usury the rate is determined by the lender and paid with the interest rate of any fixed or predetermined rate (Nademi, 2013, 28). Research conducted at Said Business School, Oxford University showed that many banks offering Islamic financial products are more attractive to non-Muslims customers than to Muslim customers. In the West Bank, HSBC Bank system product portfolio and Sediq Charters Bank have created strong connection in both parts with Islamic products. Purely Islamic banks, like Alrajhi Bank Saudi Arabia, have well developed their strategies in different countries for non-Muslim audience and attracted customers from different cultures. Although the share of Islamic financial transactions in the world is small, fast-growing and innovative products production flows.

\section{Products related to lifestyle and fashion}

In addition to media and magazines, lifestyle and beauty products, fashion, and Islamic clothes in the world have begun to flourish, and offer women a variety of products that would combine design with Islamic principles. 


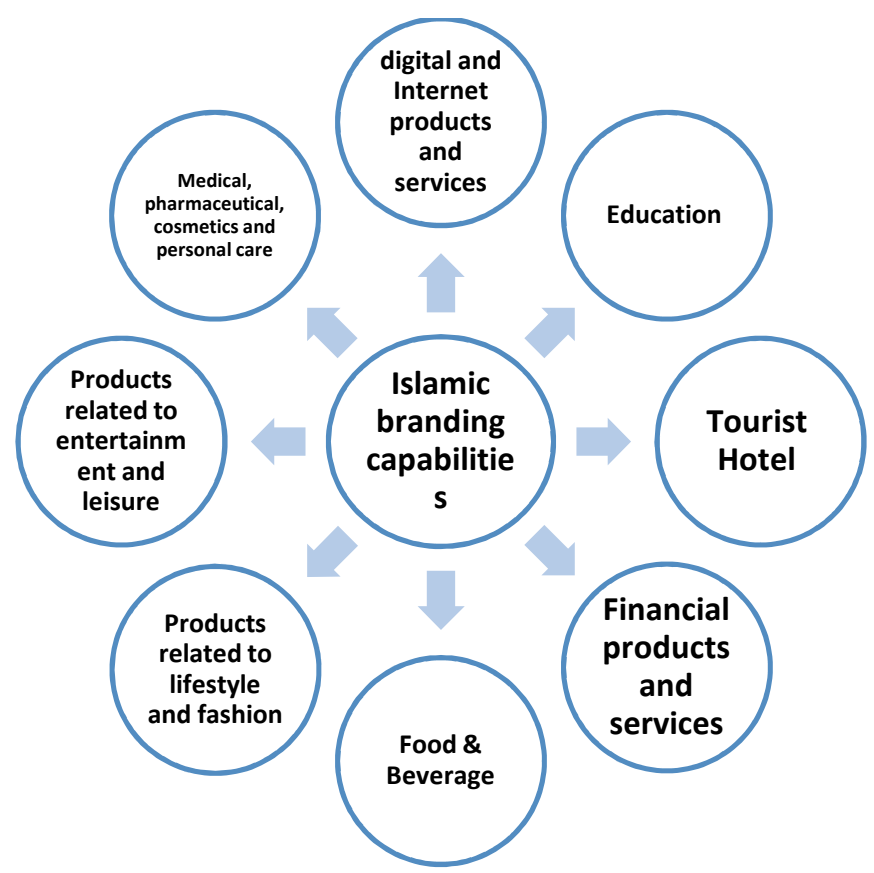

\section{THE CHALLENGES FACING THE ISLAMIC BRANDING AND MARKETING}

Remember that although the entire Muslim world market is massive, it is not a market with uniform behavior. Virtually similarities and differences can be observed in countries where Muslims live. This means that any brand that wants to take advantage of multiple markets Muslims cannot rely on one brand strategy. Because of some reasons, these changes in the markets are some specific challenges that must be dealt with in formulating multiple marketing strategies. Before we consider the existing strategies, we will look at the main challenges facing the Islamic companies that want to gain a good foothold in both Islamic and non-Islamic markets and build strong brands.

\section{The main challenges}

Islamic brands try to gain a share in selected markets, especially where Western brands have had far superior positions. Islamic brands have to overcome a variety of challenges, the most important of which are:

1. Knowledge: gaining brand awareness

2. Availability: guaranteeing accessibility

3. Acceptability: obtaining acceptance

4. Sufficiency: meeting standards and good and compatible quality

5. Intimacy: Gaining confidence

6. Attack: Attack of the competitor brands

\section{Gaining brand awareness}


One of the most fundamental obstacles to the growth of Islamic brands is to achieve brand awareness on arrival to the densely populated markets, where most Western brands are fluent, especially if the product is not specifically aimed at Muslim audiences. In particular, there are some strategic questions that must be answered, such as: How can these obstacles be resolved considering the consumer try, his purchase, and his priorities now that there is loyalty to other brands available? It is not easy and even if there is a strong leader in the group, (which often happens in consumer markets), current players may encounter problems. For example, in the clothing and sports shoes markets, Nike has about 40 percent of the world's market and Adidas is the other brands behind it. Similarly, for years, Nokia mobile phone has allocated nearly 40 percent of the annual market share to itself, and even the closest competitors (like Samsung and LG) have tried to be close to the leader, while previous leaders and famous brands such as Motorola now have a small part on the market. It is scary to acquire knowledge and enter these markets, but it is doable. For example, although HTC is not an Islamic brand, in about 10 years from an OEM (Original Equipment Manufacturer) of mobile phones, it has turned into a fast-growing brand with revenue of $\$ 3$ billion in 2008. It has not lost its OEM business, because it is now making an important component of the Nexus One (Google's new smartphone).

\section{Ensuring availability}

The second challenge for Islamic companies that wish to create their own brands is the issue of how the get access to the populous markets. To be successful as an international brand, particularly in the consumer retail goods and fast stimulating goods, getting a large share of distribution is important. This can be difficult in existing markets. For example, obtaining the shelves of supermarkets in major cities is very difficult for smaller brands, because the main actors are very dominant in front of the eyes of the consumer. Thus, grabbing a foothold in the market not only requires a wide range of products with high appeal to consumers, but above all it requires the ability to distribute brands available to consumers as well.

There are two ways to solve this problem: First, creating an alliance or strategic partnership with major retailers, and the second following a special target market with a carefully planned distribution to avoid competing with the existing brands, and perhaps their encouraging to give space to you, because you have been influential in the market.

\section{Gaining competence and acceptance}

Many factors hinder the acceptability of a brand by consumers, one of which is the country of origin. In the absence of strong branding, consumers are highly responsive to risk and do not 
want to buy products from countries they are skeptical about. Prejudice to a brand that is perhaps conceived of an Islamic country can take different forms. For example, companies that are working under the name of "Made in Iran" and want to find their way to markets in the United States may not see this very useful in marketing of their products, while with the label "Made in Malaysia" probably, they will not be faced with such obstacles. Conversely, a label "Made in Iran" in a Muslim country that is more traditional and conservative such as Yemen or Afghanistan could be acceptable or even sell more product than Malaysia product. Here the important thing is not religion, but the subjective effect of the country of origin of a brand. How are the mental communications for a consumer when a product is associated with a particular country? Brand owners have to decide whether to include the country of origin on the scene or not and market research can determine what communication to convey brand image is useful.

As a result, care should be taken careful to know how market feels about your brand's country of origin, and joining this association with your brand will have positive or negative impact for short-term and long-term development of the brand and the market.

\section{Gaining standards and good and compatible quality (competency)}

Competency means the ability of a company to produce branded high quality products and services for markets is acceptable to them. Building and maintaining a strong brand preference are impossible in the absence of product quality and service. There is no exception to this rule. Manufacturing products with a quality, less than your competitors or offering a disappointing experience to your users prevents you from becoming a brand strong brand and can even jeopardize your business in the environment. If you want to function well in halal markets, you have to make sure that you have sufficient authority and credibility of the competent authorities concerned.

\section{Halal Standards}

Verifying halal standardization has been discussed many years, but still there are different standards between countries. This position makes a multinational or global overtaking difficult for any player in the halal food. The need for standardization of approvals and permits and particularly labeling is agreed upon in all halal conferences, but OIC countries seem unable to agree on what standards should be applied.

\section{Gaining confidence (intimacy)}

A must for any global or international brand that is high-flying is intimacy, which means trust. Without trust, there is no loyalty, and customers will not stay with your brand. A good 
example of the proximity between a brand and its customers is Apple. When people are the customers of the brand, despite suggestions that competitors offer, they will hardly leave it. Most global brands have this brand power. One of the elements that create trust is quality as mentioned above as one of the requirements. Quality of service is another element that affects brand trust. In general, in Asian countries, quality of service is still variable; this quality is only in more affluent and higher stores such as classy hotels and boutiques. There is no stability and consistency and therefore it shows an opportunity.

\section{Attack by the rivals of a brand}

The last challenge of branding is actual attack by the main competitors, particularly from global brands. Opportunities in Muslims markets have attracted a large number of nonMuslim companies and main companies move quickly and deeply into this market and have a powerful position known and respected in the Islamic world. They quickly understand that Islamic market in its integrity is responsible for one fourth of the population of the earth and compared to that they are not exploited.

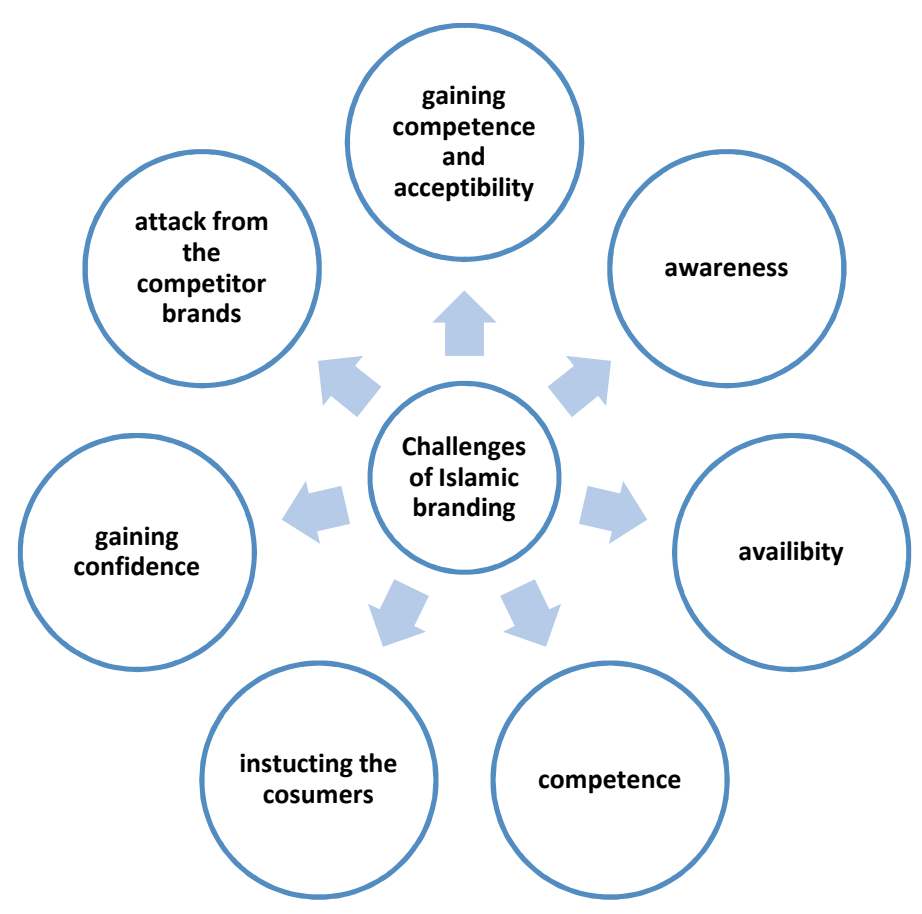

\section{CONCLUSION}

Brands bring jobs and wealth the country and can accounted for $70 \%$ of the value of the stock exchanges. They are invisible capitals with a different share and can bring a stable flow of income during the decades. The main gaps in the companies approach in Muslim countries in branding and marketing companies compared to Western brands include firstly, an unknown 
soul / brand identity and second, the relative lack of marketing investment. There is a wide range of goods production where Islamic brands can benefit and have acceptability. Despite the fact that there are many opportunities in this area, overall, companies in the Islamic world have been slow in understanding the idea of creating brands and have been largely unsuccessful in this area. This is because they have not acted wisely in type of creative thinking and have not used the scope of Islamic values to create and develop their own brands. On the other hand, many factors can create barriers to the growth of the brands coming from the Muslim world. However, if the right strategies are used, these challenges are not insurmountable. Creating products with a unique identity, based on basic goals and values of Islam and a reviving culture of innovation and development of innovative and competitive marketing strategies are of proposed methods to eliminate obstacles in the Islamic branding and marketing.

\section{REFERENCES}

[1] Temporal, P, 2012, Islamic branding and marketing, translators Ahmad village and Ali Salehi, Tehran, trade publication

[2] The world economy. Temporal, Paul, 2012, Islamic branding and marketing, translators Ahmad village and Ali Salehi, Tehran, trade publication

[3] The world economy, Number 3108, dated January 11, 2014, page 28 (Economic Thought).

[4] Naderan, E., 2003, Globalization, what to do in the universality of Islam, Vol. 2, The World Forum for Proximity of Islamic Schools of Thought, p. 31

[5] Nozari, H., 2004, The Asia Cultural Institute of Contemporary Abrar International Studies, Tehran, Page 111.

[6] , No. 3108, dated 92/10/21, page 28 (Economic Thought).

[7] Naderan, E., 1382, Globalization, what to do in the universality of Islam, Vol. 2, The World Forum for Proximity of Islamic Schools of Thought, p. 31.

[8] Nozari, H., 1383, The Asia Cultural Institute of Contemporary Abrar International Studies, Tehran, Page 111.

[9] Paul Temporal, 2011, Islamic Branding and Marketing: Opportunities and challenges [10] “The Global Halal Food Industry Revisited”, The Halal Journal, May/June 2009.

[11] The banker, nowember 2008.

[12] www.ihialliance.org/home.php 
[13] http://www.europeanfinancialreview.com/?p=2829

\section{How to cite this article:}

Tabatabai Nasab M and Banejad B. Marketing and branding in Islamic countries, challenges and capacities. J. Fundam. Appl. Sci., 2016, 8(3S), 721-737. 